$1-1-1976$

\title{
Satisfaction with community services in northern West Virginia
}

John P. Kuehn

Follow this and additional works at: https://researchrepository.wvu.edu/ wv_agricultural_and_forestry_experiment_station_bulletins

\section{Digital Commons Citation}

Kuehn, John P., "Satisfaction with community services in northern West Virginia" (1976). West Virginia Agricultural and Forestry Experiment Station Bulletins. 649.

https://researchrepository.wvu.edu/wv_agricultural_and_forestry_experiment_station_bulletins/551 @ WVU. It has been accepted for inclusion in West Virginia Agricultural and Forestry Experiment Station Bulletins by an authorized administrator of The Research Repository @WVU. For more information, please contact ian.harmon@mail.wvu.edu. 
Satisfaction with

Community Services in Northern West Virginia

Bulletin 649

October 1976

Agricultural and Forestry Experiment Station

West Virginia University
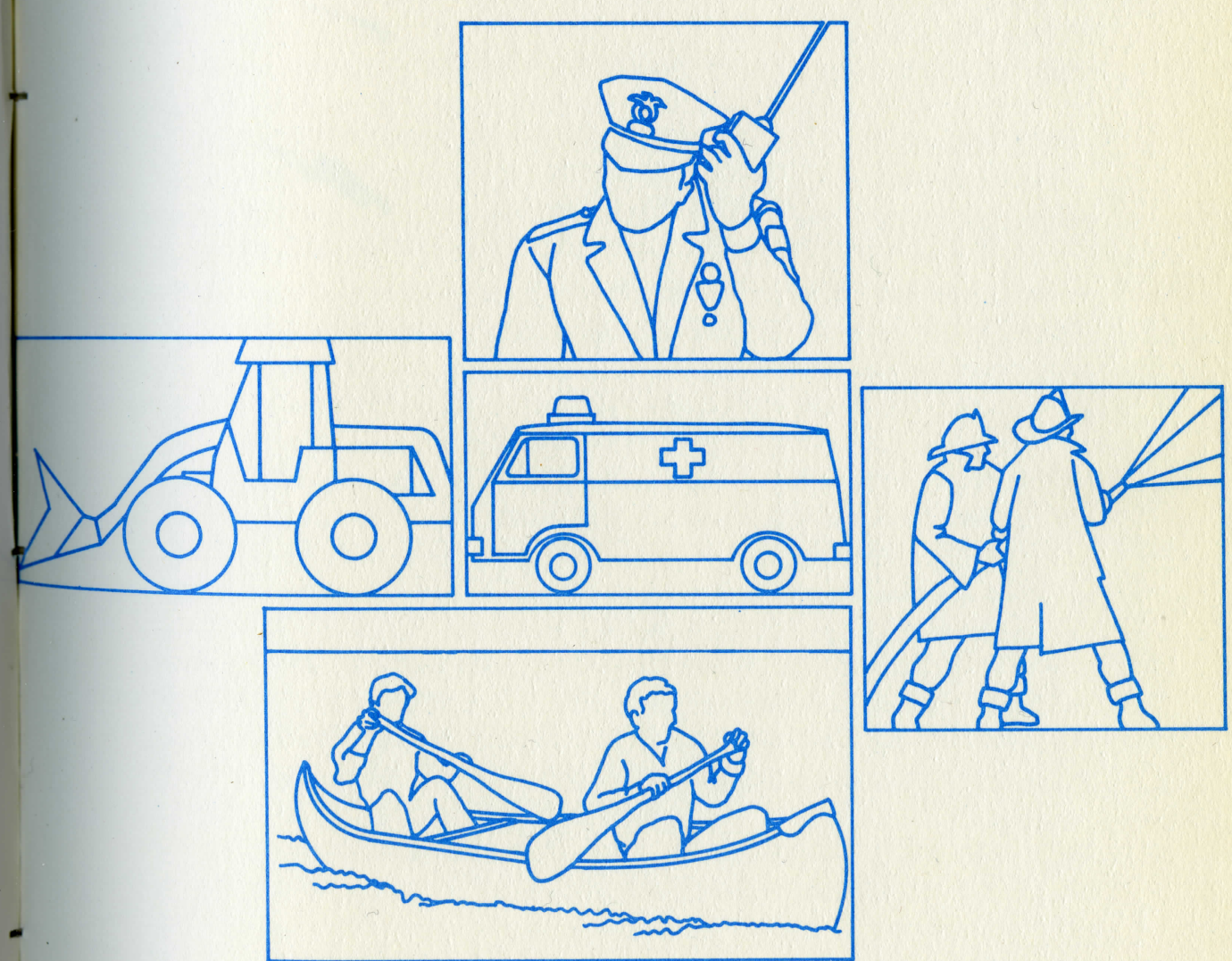


\section{THE AUTHOR}

John P. Kuehn is Associate Agricultural Economist.

\section{ACKNOWLEDGMENT}

This bulletin is published as a contribution to the Northeast Regional Marketing Research Project (NE-77). The West Virginia research for this publication was supported by both state and regional research funds.

\section{Summary and Conclusions}

The objective of this study was to determine the levels of satisfaction with iect community services in an 11-county area of northern West Virginia and to compare these levels to those of selected sites in the non-metropolitan Northeastern United States. Also, an objective was to determine what factors affect these satisfaction levels.

Out of 245 non-metropolitan counties in the Northeast, 15 sites were selected in nine states based on population and income changes between 1960 and 1970. Although the regional sample was not designed to be a representative sample of the Northeast, the individual sites (including the three West Virginia counties) were stratified on the basis of population density and randomly sampled with the use of map grids.

The West Virginia portion of the sample was designed with a dual purpose. Three counties-Monongalia, Marion, and Harrison-were chosen, along with the other 12 sites in the Northeast, to sample various aspects of community services in the non-metropolitan Northeast. These three counties were also chosen as a representative sample of 11 counties in northern West Virginia.

A total of 2,141 questionnaires was completed in the Northeast; 295 of these were in West Virginia. The questionnaire contained seven major categories: household information, health services, educational services, legal services, housing, satisfaction items, and income. This bulletin contains an analysis of the satisfaction items: local ambulance, housing situation, local road maintenance, medical services, dental services, local schools, neighborhood, local fire department, local police, sports and recreation programs, telephone service, public transportation, information about local events in local papers, information about local events on television, and information about local events on radio.

When all services included in the study were considered, West Virginians sampled were quite satisfied. On a six-point scale ranging from unsatisfied (1) to very satisfied (6), West Virginians averaged 5.04. Respondents to the regional questionnaire averaged 4.96 , which was slightly less than moderately satisfied. Typically, West Virginians were more satisfied with ambulance, medical, dental, telephone services, neighborhoods, public transportation, and information about local events on radio and television. Regional respondents tended to be more satisfied than West Virginians with housing, local road maintenance, schools, fire and police departments, sports and recreation programs, and information about local events in newspapers.

When services were ranked by satisfaction level, the West Virginians sampled were most satisfied with their neighborhoods (ranked 1), dental services (2) and with information about local events on radio (3). They were least satisfied with sports and recreation programs (12), housing (13), public transportation (14), and local road maintenance (15) 
Respondents to the regional questionnaire ranked satisfaction with fir departments, neighborhoods, and ambulance services as one, two, and three. And, although the rank order was different, both the regional respondents and the West Virginians sampled placed the same four services at the bottom of the rankings. Regional respondents, however, were more satisfied than West Virginians with each of the last four services, except they were much less satisfied with public transportation.

When mean levels of satisfaction were compared, older respondents, generally, were more satisfied than younger respondents with a composite index of all of the services included in the study. Also, satisfaction with this composite tended to decrease as family size increased. When education was considered, the more highly educated West Virginians sampled were more satisfied than those with lower levels of education. In the Region, however, satisfaction decreased as education increased.

The statistical analysis showed that socioeconomic factors such as age and education of household head, family size, length of residence, marital and labor force status, and income had very little effect on satisfaction with community services. The total amounts of satisfaction explained by these variables were statistically shown to range from no effect to about 16 percent. The remainder of this explanation was hypothesized to be due to factors specific to the location, such as the quality of the particular service.

\section{Satisfaction with Community Services in Northern West Virginia}

\author{
John P. Kuehn
}

"It is generally recognized that the kind, quality, and cost of public and private community services ... are among the important influences upon rural development. The range in community services among rural localities, and among rural as compared with urban localities, tends to be very great."1

The fact that community services vary by area implies that the socialeconomic-political interstructure could have some influence on the equitability of services between areas. "The reduction in inequities in the availability and quality of community services among rural areas and between rural and urban areas should improve rural living, contribute to the development of rural communities, be a factor working toward a better rural-urban balance in the distribution of population, and reduce the heavy social costs of rural-to-urban migration."2 The adjustments required in rural-urban balance might be further complicated by an apparent reversal of this long term rural-to-urban migration. Beale $^{3}$ found that between April 1970 and July 1973 the population of nonmetropolitan counties increased 4.2 percent compared to only a 2.9 percent increase in the metropolitan population. The implications of this reversal are difficult to evaluate since many rural areas have been in the process of adapting to out-migration.

The levels of population in rural areas and the changes in these levels can be expected to have an effect on the "quality of life." Some of these factors have been investigated. One example is the possible positive correlation between standard of living (income level) and satisfaction with life. Marans and Rogers found, however, that people with the lowest standard of living expressed the greatest satisfaction with their lives. "Furthermore, those most satisfied of all are those living in rural areas."

${ }^{1}$ Project statement for Northeast Regional Research Project Number 77, "Community Services for Non-metropolitan People in the Northeast," p. 3.

${ }^{2} I b i d$. p. 4.

${ }^{3}$ Beale, Calvin L., The Revival of Population Growth in Non-metropolitan America, ERS-605, Economic Research Service, U. S. Dept. Agric., June 1975.

${ }^{4}$ Marans, Robert W. and Willard Rogers, "Toward an Understanding of Community Satisfaction," Institute for Social Research, The University of Michigan, December, 1972. (Mimeo). 
Results of these and similar studies raise questions regarding satisfaction with community services. How satisfied are West Virginians with community services? What factors affect satisfaction with community services? The overall objective of this study was to answer these questions.

\section{SAMPLING PROCEDURE ${ }^{5}$}

This study is part of a Northeast regional analysis of the delivery of community services to non-metropolitan people. The non-metropolitan sector for this project was defined as those people living in counties with a 30 percent or greater non-urbanized population. Using this criterion, 245 non-metropolitan counties were identified and classified on the basis of population change (1960-1970) and income change (1960-1970). This was done in order to select "more developing" and "less developing" counties for inclusion in the analysis.

Fifteen sites (a site was either a single MCD, a grouping of contiguous MCDs, a county or a combination of counties) were selected in nine states in the Northeast. Each of the sites was stratified on the basis of population density and random samples were taken.

The procedure provided a sample that reflected geographic dispersal of households (the basic consuming unit), permitting the testing of the hypothesis that location or distance affected or acted as a barrier to community service use. (However, the total sample was not designed to be a representative sample of the Northeast.) Interviews took place in a total of 2,141 households. The typical interview took about 45 minutes.

\section{SAMPLE SITE CHARACTERISTICS}

Table 1 shows the population, population change, developmental status, and density for each of the sites included in the study. The first four sites (MD, NY, PA and WV) included only counties. The remaining sites were composed of towns within counties. For purposes of analysis, the individual sites were combined in each state (Figure 1).

Table 2 describes the sample characteristics of each of these "combined" sites. The MA sample had the oldest group of respondents while ME had the youngest. The largest family size was encountered at ME while the smallest was found in the WV sample. The best education levels were found at NJ site while the ME sample exhibited the poorest average education. The PA respondents had the longest average length of residence while the $\mathrm{NJ}$ respondents had the shortest. Income was highest at the MD site and lowest in the NH sample.

${ }^{5}$ For a complete explanation of the sampling procedure, see Appendix.
Figure 1 - Outline Map of Northeast Showing Counties Selected as Study Sites

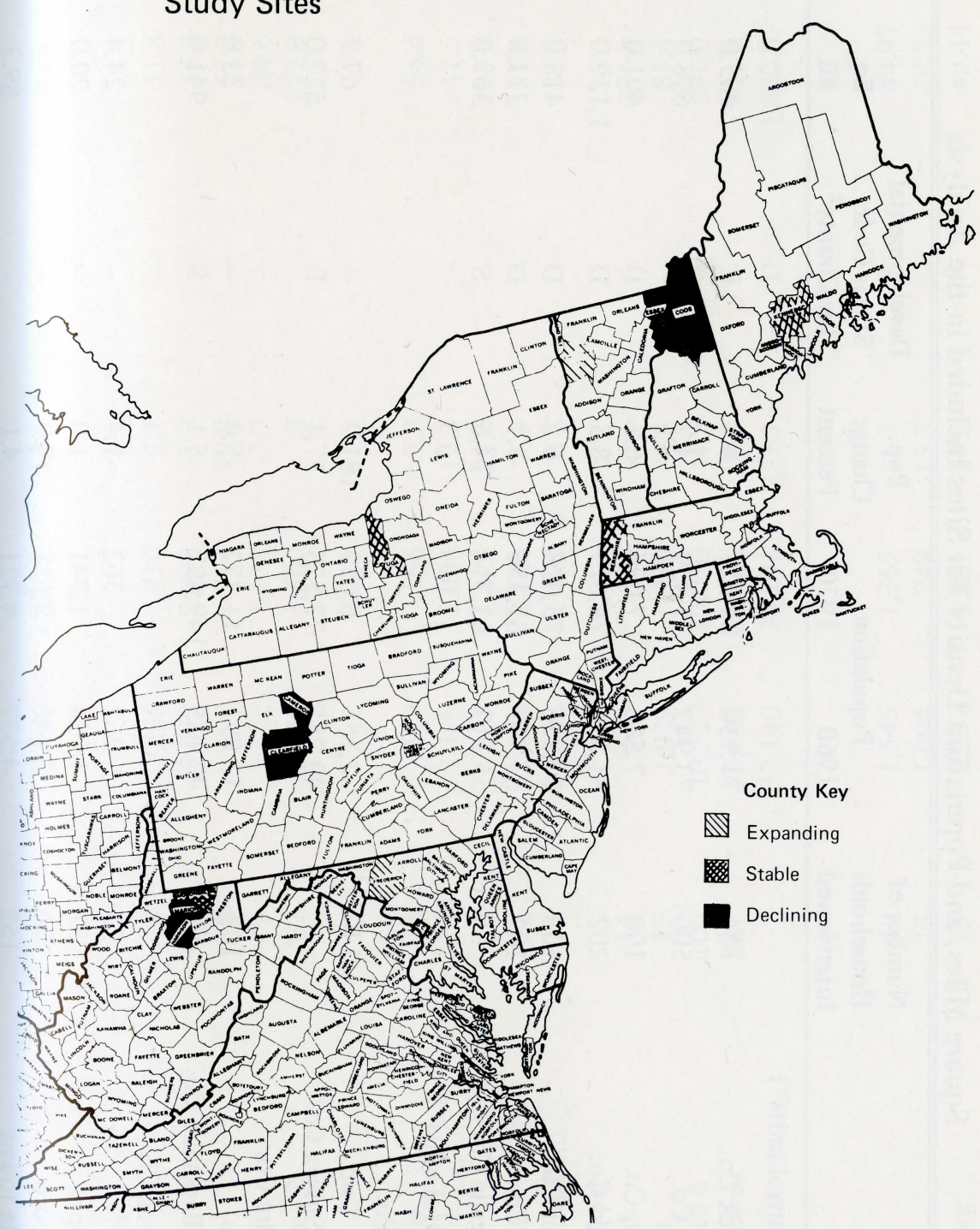




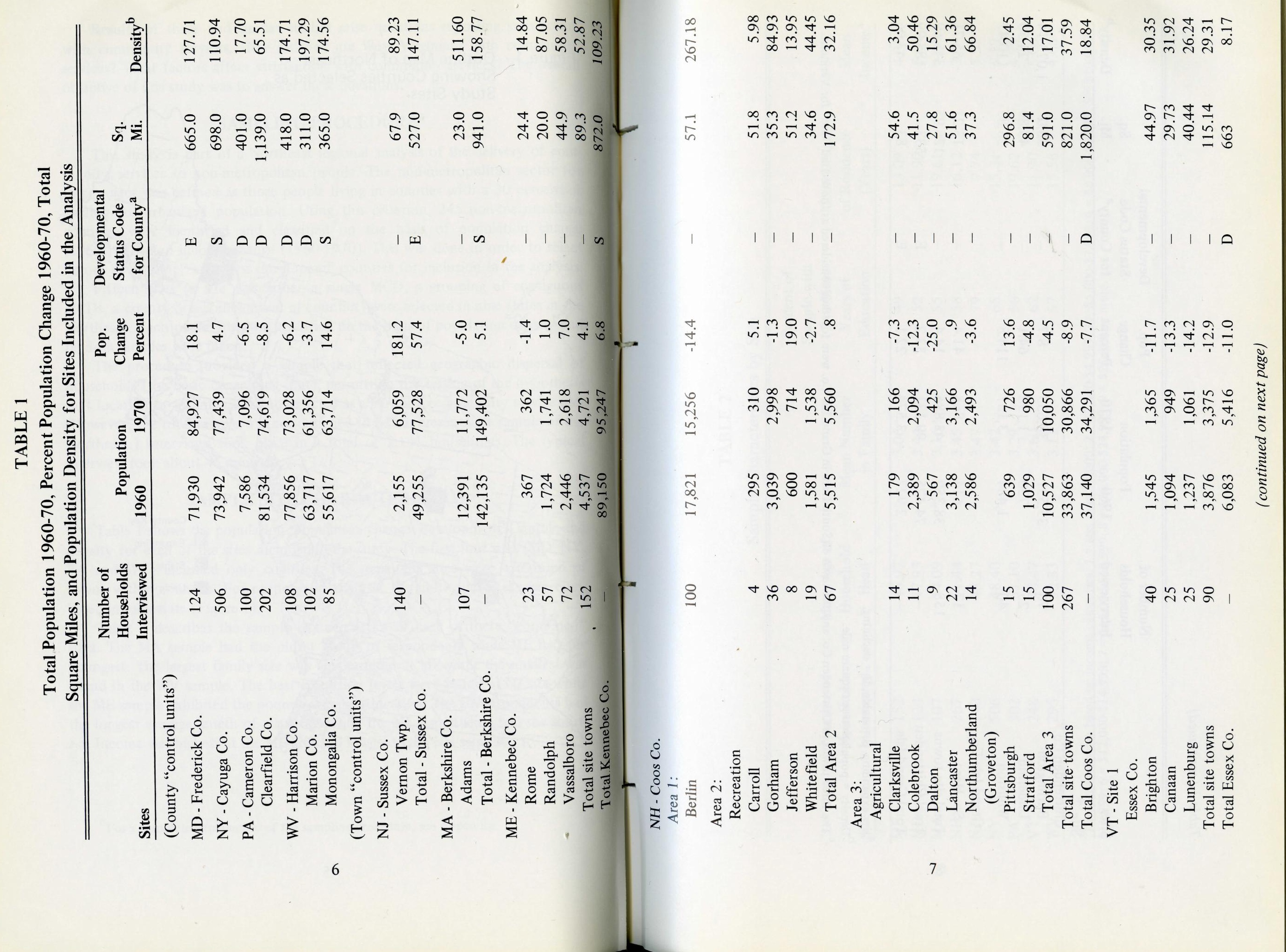



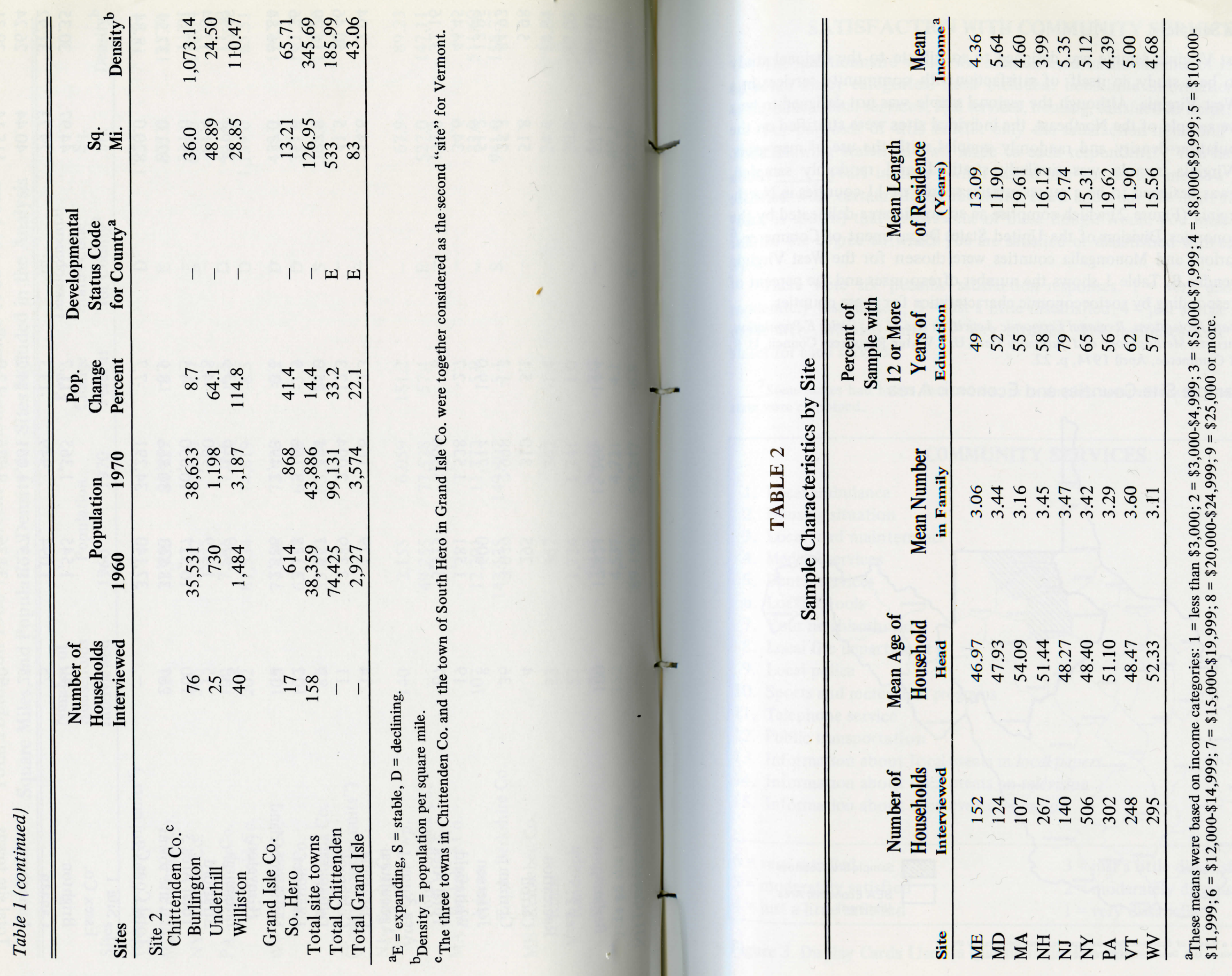


\section{West Virginia Sample}

The West Virginia samp!e was designed to contribute to the regional study as well as to be a study, in itself, of satisfaction with community services in a portion of West Virginia. Although the regional sample was not designed to be a representative sample of the Northeast, the individual sites were stratified on the basis of population density and randomly sampled with the use of map grids. The West Virginia sample was similarly stratified and randomly sampled. However, it was designed to be a representative sample of 11 counties in North ern West Virginia (Figure 2) which comprise an economic area delineated by the Regional Economics Division of the United States Department of Commerce. ${ }^{6}$ Harrison, Marion, and Monongalia counties were chosen for the West Virginia sample. Appendix B, Table 1 shows the number of responses and the percent of households responding by socioeconomic characteristics for these counties.

${ }^{6} 1972$ Obers Projections, Regional Economic Activity in the U. S., Series E Population, Volume I, Concepts, Methodology and Summary Data, U. S. Water Resources Council, U. S. Department of Commerce, April 1974, p. 22.

Figure 2. Sample Site Counties and Economic Area ${ }^{a}$

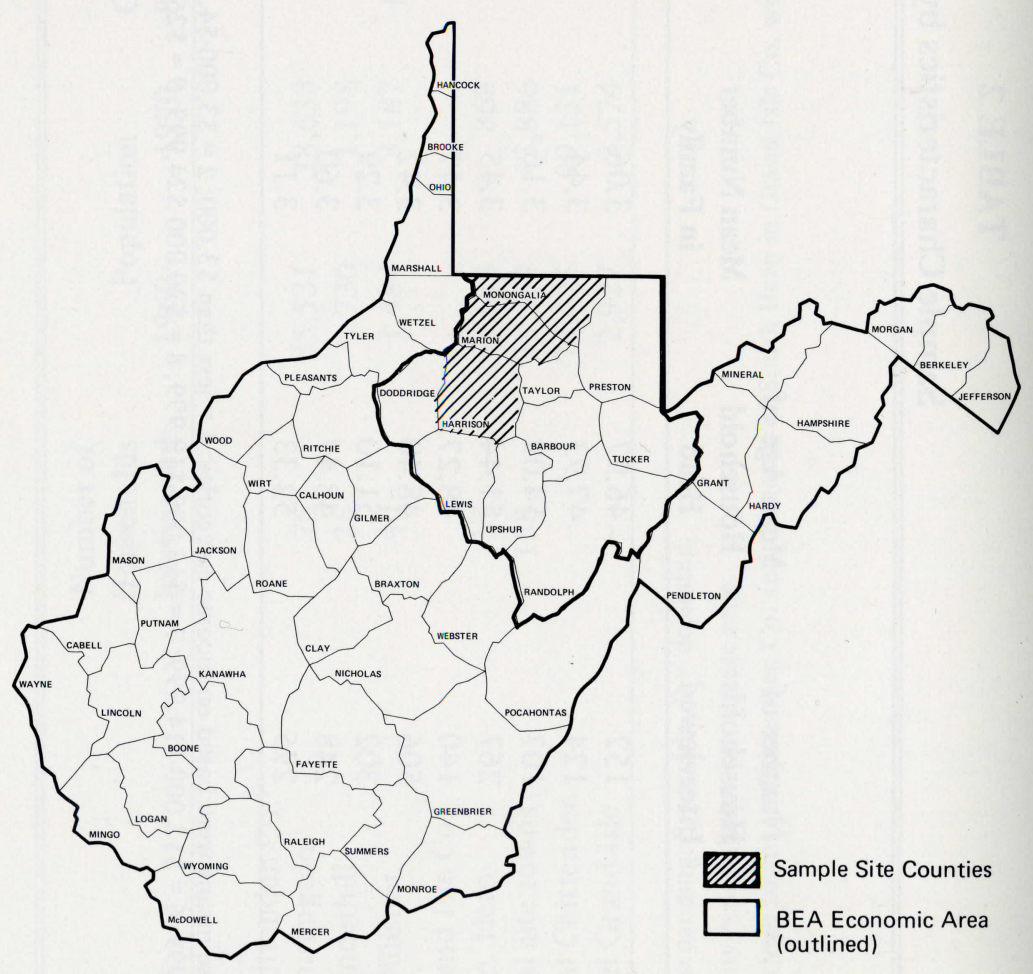

a The outlined area is a Bureau of Economic Analysis Economic Area delineated by the
Regional Economics Division, U. S. Department of Commerce.

\section{SATISFACTION WITH COMMUNITY SERVICES}

The questionnaire which was administered in the summer of 1974, contained seven major categories. These included: household information, health services, educational services, legal services, housing, satisfaction items, and income.

For purposes of this bulletin only the satisfaction items will be analyzed. The following statement was made to each respondent: "You have now lived about___ years in this town. I would like you to tell me how well you are satisfied with certain things about the town and your life in it. Here is a card (card is shown) that shows some of these things. Would you look at them and tell me the degree to which you are satisfied or dissatisfied with each." (Figure 3).

There were six possible satisfaction responses: $1=$ very dissatisfied; $2=$ moderately dissatisfied; $3=$ just a little dissatisfied; $4=$ just a little satisfied; 5 = moderately satisfied; and $6=$ very satisfied. The responses were averaged by states for each service. ${ }^{7}$

${ }^{7}$ Some states had more than one site, so to simplify comparisons all sites in a particular state were combined.

\section{COMMUNITY SERVICES}

1. Local ambulance

2. Housing situation

3. Local road maintenance

4. Medical services

5. Dental services

6. Local schools

7. Your neighborhood

8. Local fire department

9. Local police

10. Sports and recreation programs

11. Telephone service

12. Public transportation

13. Information about local events in local papers

14. Information about local events on television

15. Information about local events on radio
$6=$ very satisfied

$5=$ moderately satisfied

4 = just a little satisfied

Figure 3. Display Cards Used In Questionnaire Procedure
$3=$ just a little dissatisfied

2 = moderately dissatisfied

$1=$ very dissatisfied 


\section{SERVICE SATISFACTION MEANS}

Means levels of satisfaction were determined for each service at each site:

$$
\bar{Y}_{i j}=\frac{\sum_{i j}}{\frac{N_{i j}}{N_{i j}}} Y_{i j k}
$$

$\bar{Y}_{i j}=$ Mean level of satisfaction with service $\mathrm{j}$ at site $\mathrm{i}$.

$\mathrm{Y}_{\mathrm{ijk}}=$ Satisfaction with service $\mathrm{j}$ at site $\mathrm{i}$ by $\mathrm{k}$ respondents.

$\mathrm{N}_{\mathrm{ij}}=$ Number of respondents to service $\mathrm{j}$ at site $\mathrm{i}$.
Sites (i)
1. VT
2. $\mathrm{ME}$
3. $\mathrm{NH}$
4. MA
5. NY
6. PA
7. NJ
8. WV
9. $\mathrm{MD}$

$1=$ Very dissatisfied $3=$ Just a little dissatisfied 4 = Just a little satisfied $5=$ Moderately satisfied $6=$ Very satisfied $2=$ Moderately dissatisfied
Weighted means of total sample satisfaction with each service were determined by the following formula:

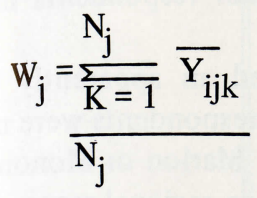

$W_{j}=$ Weighted mean of total sample satisfaction with service $j$.

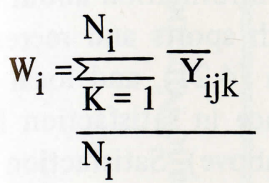

\section{$\mathrm{W}_{\mathrm{i}}=$ The weighted mean of satisfaction with a composite of all services} at each site.

\section{Services (j)}

1. Ambulance

2. Housing

3. Road Maintenance

4. Medical

5. Dental

6. Schools

7. Neighborhood

8. Fire Department

9. Police Department

10. Sports and Recreation

11. Telephone Programs

12. Public Transportation

13. Information about local events in: Newspapers

14. Television

15. Radio 
Harrison County respondents were more satisfied with the composite of community services than were those from Marion and Monongalia counties. Residents of all three counties were more satisfied than respondents in the regional sample (Table 3 ).

Satisfaction levels of two of the services exhibited an apparently large divergence between counties. Although Harrison County respondents were much more satisfied with housing and road maintenance than Marion or Monongalia County residents, they were not as satisfied as the average regional respondent.

Table 4 shows that West Virginians sampled were most satisfied with their neighborhoods (5.69), dental services (5.63), and with information about local events on radio (5.63). They were least satisfied with sports and recreation programs (4.29), housing (4.28), public transportation (4.21), and local road maintenance (3.37). There was a rather large difference in satisfaction levels between the first 11 rankings and the last four (listed above). Satisfaction with schools was ranked 11 of 15 . The mean level of satisfaction with schools was 5.00. Sports and recreation programs were ranked 12 with a mean level of satisfaction of 4.29 .

Respondents in the Northeast Region ranked satisfaction with fire department, neighborhood, and ambulance services as one, two, and three. And, although the actual order was different, the same four services were ranked at the bottom by regional respondents as by West Virginians sampled. The regional rankings were housing (12), sports and recreation programs (13), local road maintenance (14), and public transportation (15). Regional respondents were more satisfied than the West Virginians sampled with each of the last four services, except for public transportation. Regional respondents were much less satisfied with public transportation (3.41) than West Virginians (4.21).

\section{Age and Satisfaction}

West Virginia respondents in the 65 -and-over age category exhibited the highest average level of satisfaction with community services, as measured by a composite index. A notable exception to this generalization was the case of public transportation, where this age group was less satisfied than the average of all age categories. The under 25 years (4.67) and the 25-34 year (4.66) categories were least satisfied with the composite of services (Table 5).

Older respondents in the region appeared to be more satisfied with the composite of community services than younger respondents. West Virginians followed a similar trend except for the 35-44-year-old age group of household heads. This group was much more satisfied (5.11) than its regional counterpart (4.88).

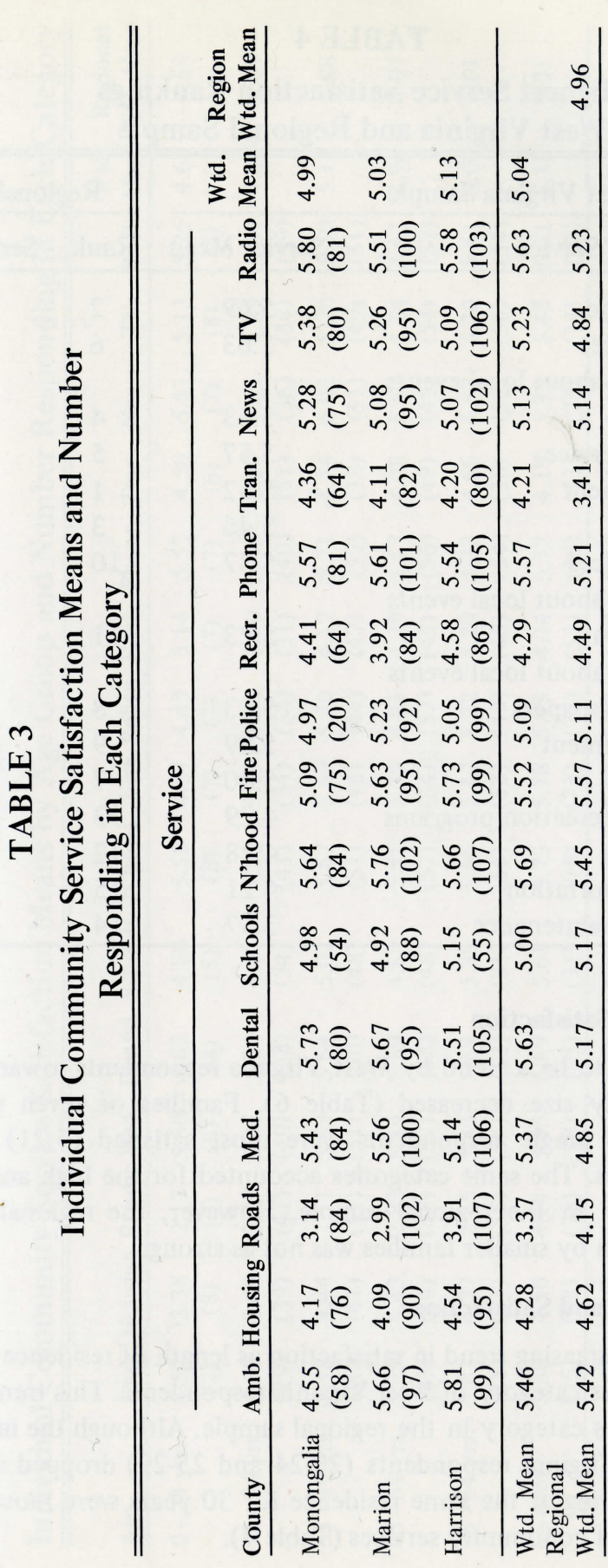

15 
TABLE 4

Highest Service Satisfaction Rankings West Virginia and Regional Sample

\begin{tabular}{|c|c|c|c|c|}
\hline \multicolumn{3}{|c|}{ West Virginia Sample } & \multicolumn{2}{|c|}{ Regional Sample } \\
\hline Rank & Service & Service Mean & Rank & Service Mean \\
\hline 1 & Neighborhood & 5.69 & 2 & 5.45 \\
\hline 2 & Dental services & 5.63 & 6 & 5.17 \\
\hline 3 & Information about local events & & & \\
\hline & on radio & 5.63 & 4 & 5.23 \\
\hline 4 & Telephone service & 5.57 & 5 & 5.21 \\
\hline 5 & Fire department & 5.52 & 1 & 5.57 \\
\hline 6 & Ambulance & 5.46 & 3 & 5.42 \\
\hline 7 & Medical services & 5.37 & 10 & 4.85 \\
\hline 8 & Information about local events & & & \\
\hline & on television & 5.23 & 11 & 4.84 \\
\hline 9 & Information about local events & & & \\
\hline & in local newspapers & 5.13 & 8 & 5.14 \\
\hline 10 & Police department & 5.09 & 9 & 5.11 \\
\hline 11 & Schools & 5.00 & 7 & 5.17 \\
\hline 12 & Sports and recreation programs & 4.29 & 13 & 4.49 \\
\hline 13 & Housing & 4.28 & 12 & 4.62 \\
\hline 14 & Public transportation & 4.21 & 15 & 3.41 \\
\hline 15 & Local road maintenance & 3.37 & 14 & 4.15 \\
\hline
\end{tabular}

\section{Household Size and Satisfaction}

There appeared to be a trend by West Virginia respondents towards greater satisfaction as family size decreased (Table 6). Families of seven were least satisfied (4.97) and single respondents were most satisfied (5.21) with the composite of services. The same categories accounted for the high and the low levels of satisfaction in the regional sample. However, the regional trend of increasing satisfaction by smaller families was not as strong.

\section{Length of Residence and Satisfaction}

There was an increasing trend in satisfaction as length of residence increased up to the 15-19 years category of West Virginia respondents. This trend extended to the 20-24 years category in the regional sample. Although the intervening categories of West Virginia respondents (20-24 and 25-29) dropped slightly in satisfaction, those living at the same residence for 30 years were most satisfied with the composite of community services (Table 7).

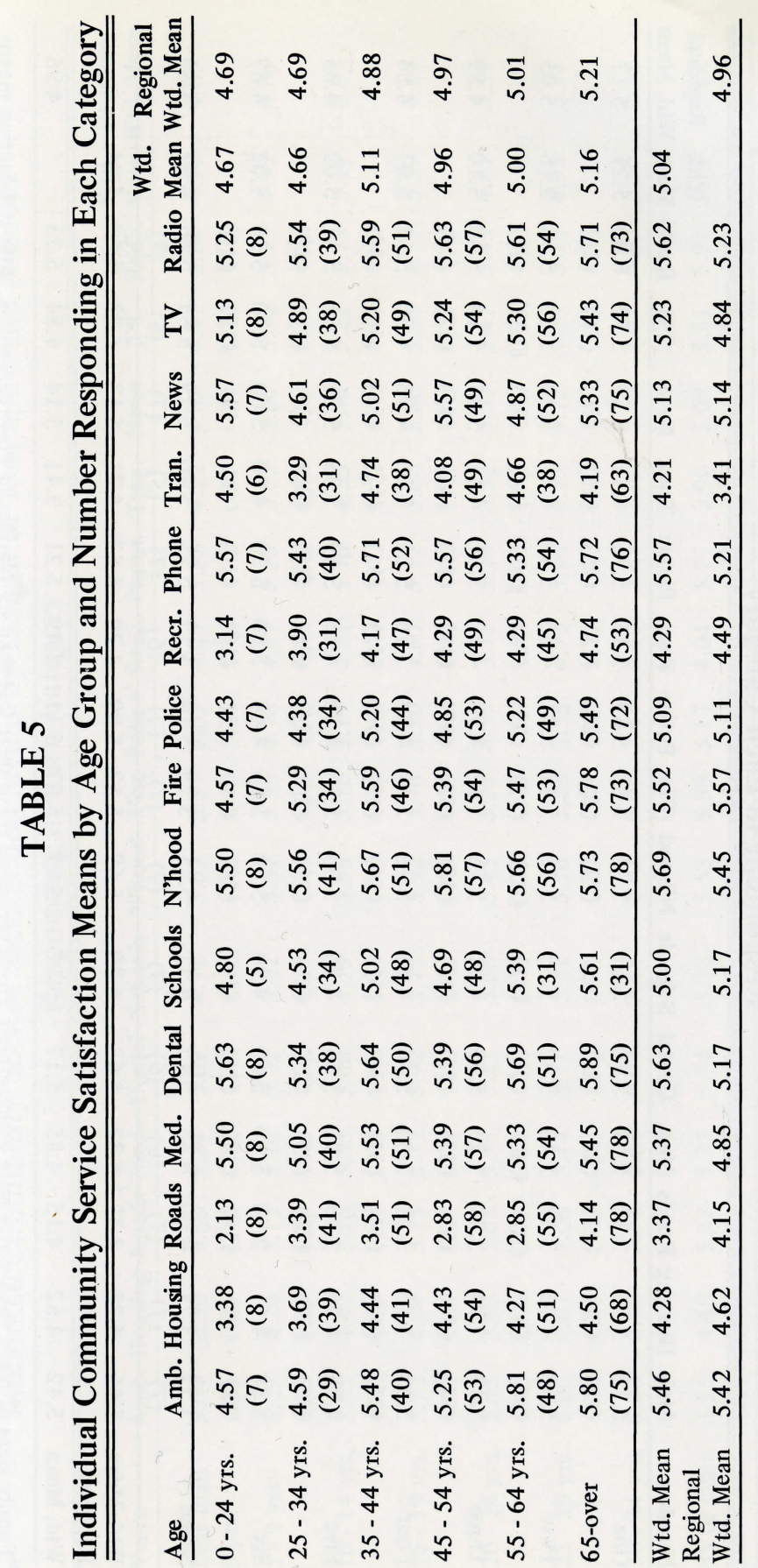

17 


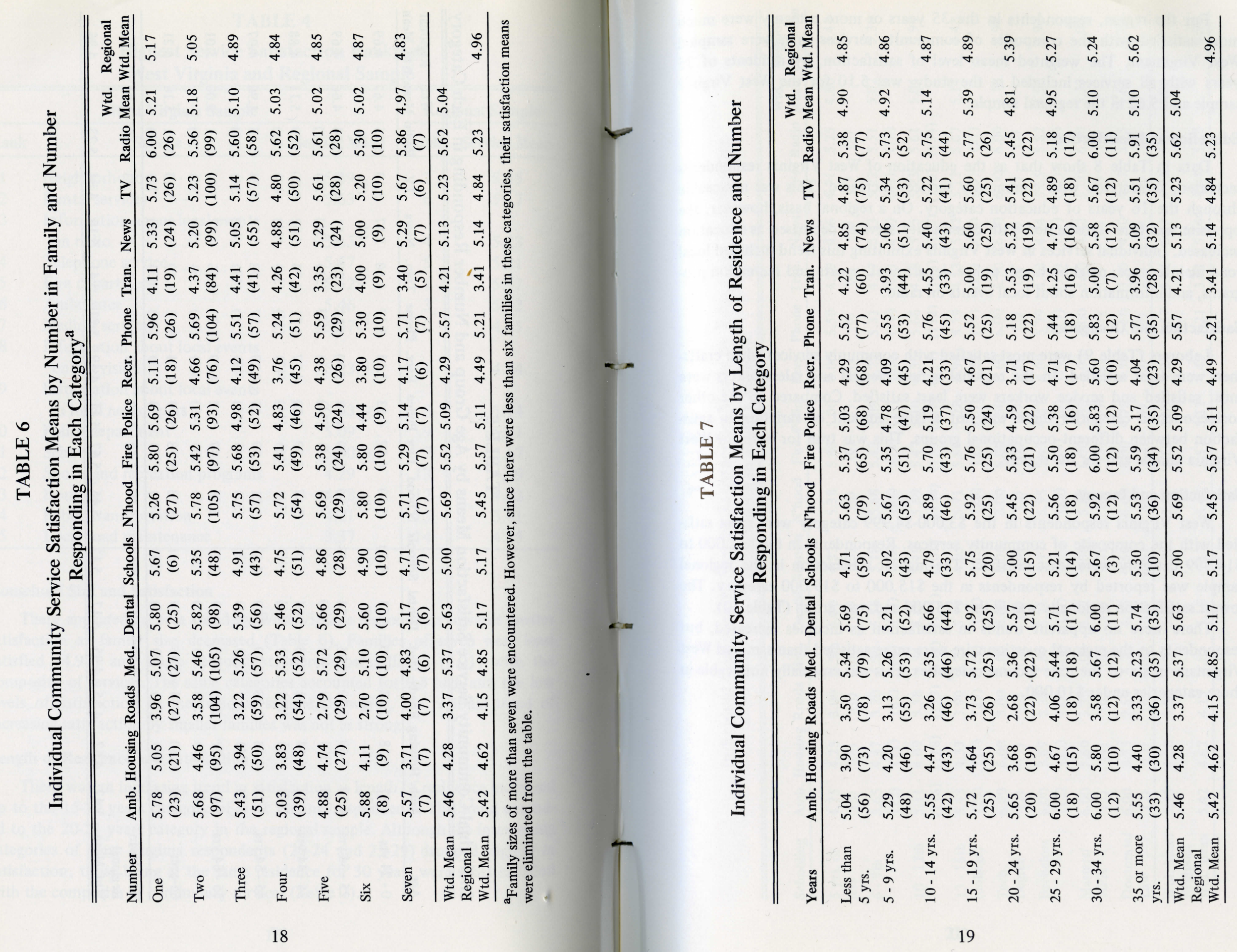


For the region, respondents in the 35 years or more category were much more satisfied with the composite of community services than were sampled West Virginians. The weighted mean level of satisfaction, by residents of 35 years with all services included in the study, was 5.10 for the West Virginia sample and 5.62 in the regional sample.

\section{Education and Satisfaction}

Data in Table 8 show that as the education of West Virginia respondents increased, satisfaction with community services increased. This was noticeable through the 16 years of education category. On a regional basis, however, the opposite was true-satisfaction with community services decreased as education increased. Individual services in West Virginia exhibiting this trend included local road maintenance, neighborhood, police department, sports and recreation programs, and information about local events on radio.

\section{Satisfaction and Occupation}

Laborers (Table 9) were most satisfied with communiy services while craftsmen were least satisfied. In the regional sample clerical and salesworkers were most satisfied and service workers were least satisfied. Compared to the other socioeconomic categories there was not a large amount of variation in satisfaction between different occupational groups. This was true for both the West Virginia sample and for the region.

\section{Satisfaction and Income}

West Virginia respondents in the $\$ 3,000-\$ 4,999$ category were most satisfied with the composite of community services. Respondents in the $\$ 12,000$ to $\$ 14,999$ category were least satisfied. The highest satisfaction in the regional sample was reported by respondents in the $\$ 15,000$ to $\$ 19,000$ category. The lowest satisfaction regionally was in the $\$ 25,000$ and over group (Table 10).

There were no apparent trends in satisfaction as incomes increased, but respondents to the regional questionnaire were more satisfied than sampled West Virginians in six of the nine income categories. This was especially noticeable in those categories under $\$ 10,000$.

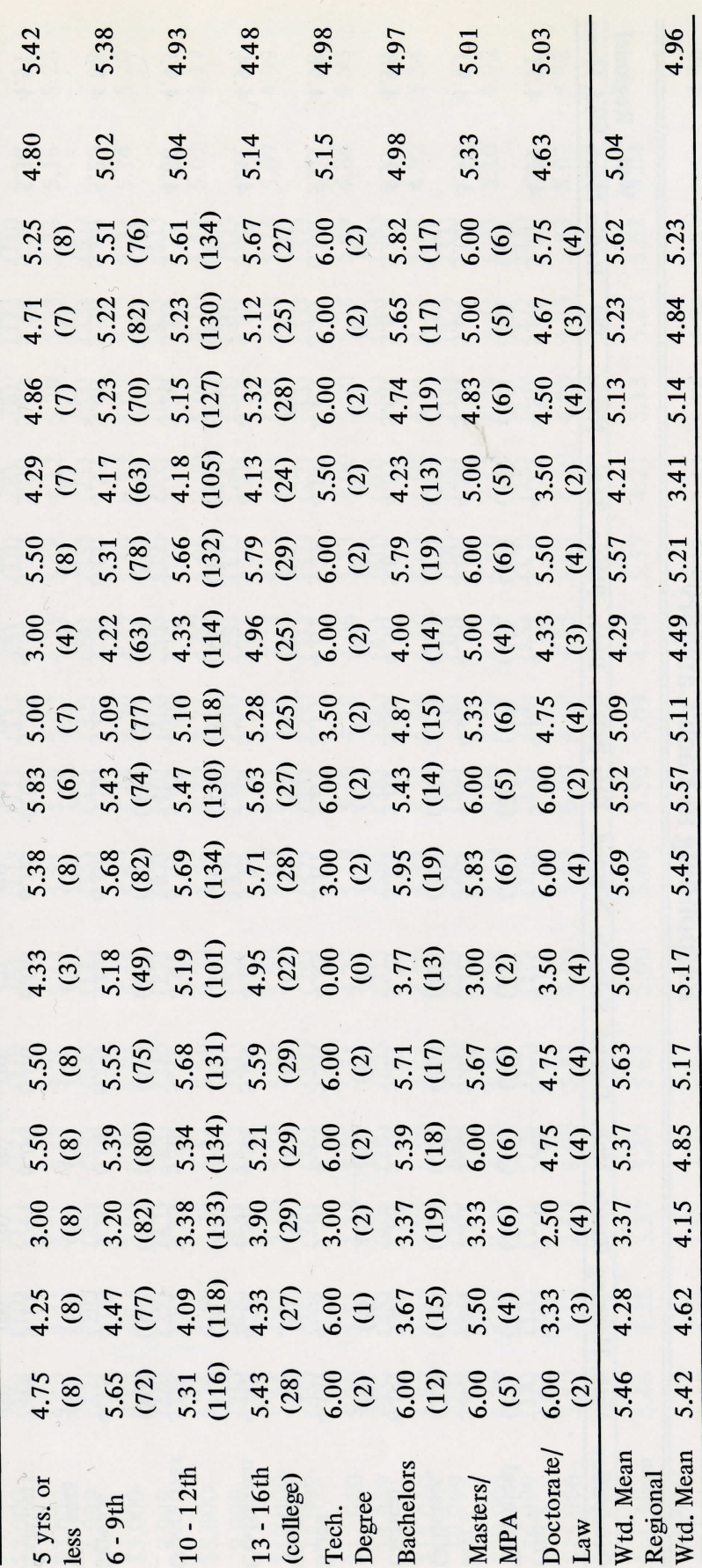

21 


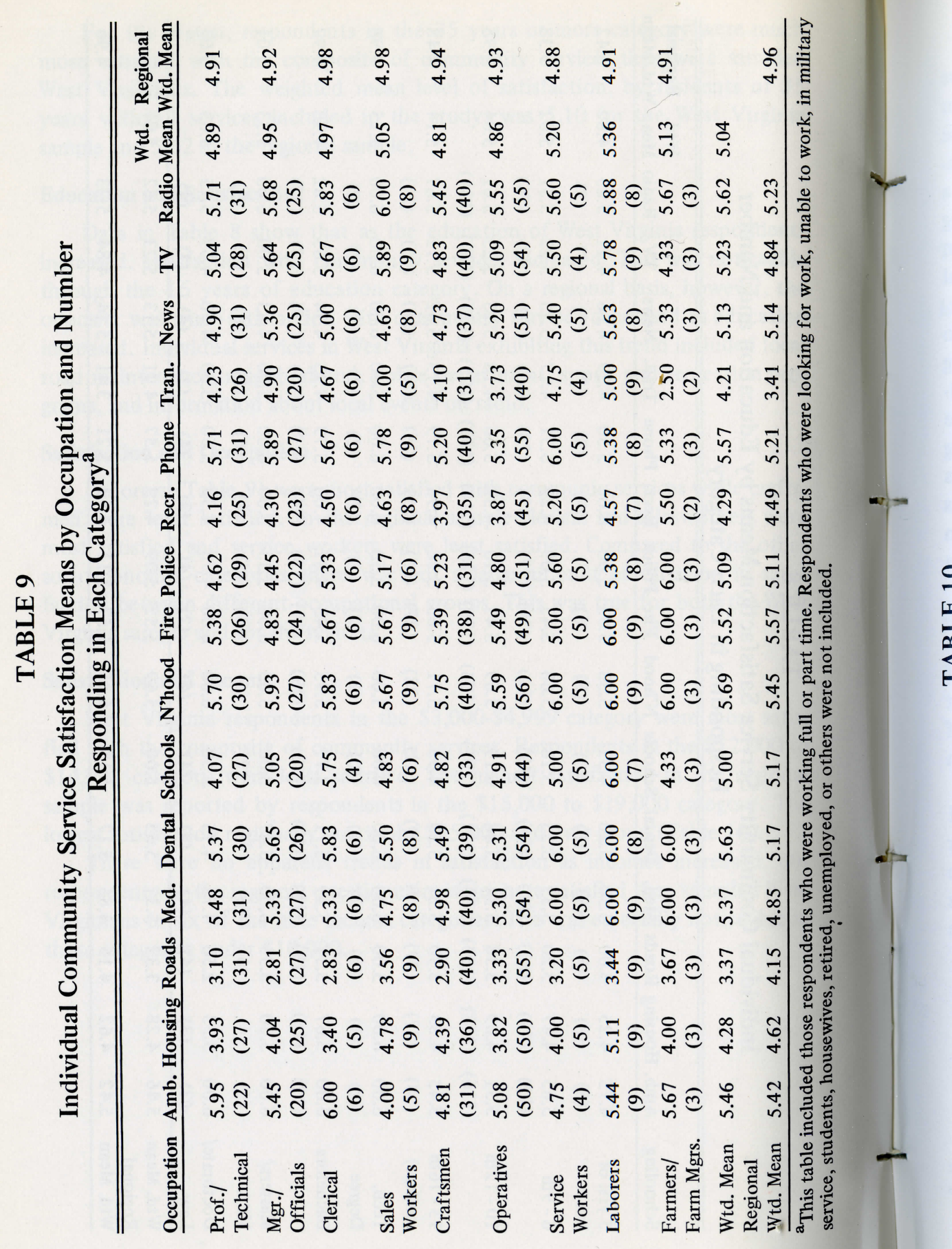

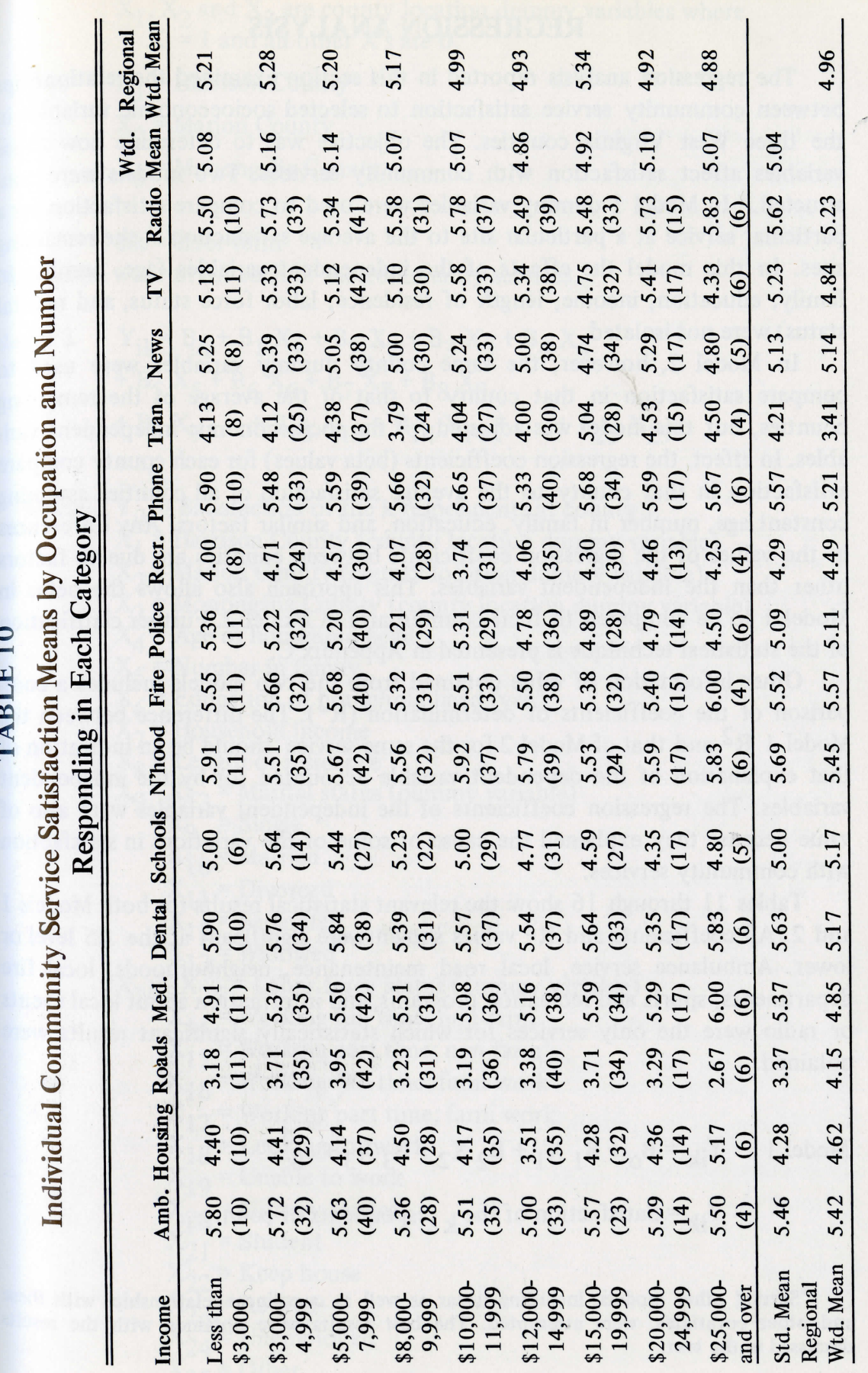

23 


\section{REGRESSION ANALYSIS}

The regression analysis reported in this section examined the relationships between community service satisfaction to selected socioeconomic variables in the three West Virginia counties. The objective was to determine how those variables affect satisfaction with community services. Two models were constructed..$^{8}$ In Model 1 dummy variables were used to compare satisfaction for a particular service at a particular site to the average satisfaction at the remaining sites. In this model the effects of the independent variables (age, number in family, education, income, length of residence, labor force status, and marital status) were not isolated.

In Model 2, however, the same county dummy variables were used to compare satisfaction in that county to that of the average of the remaining counties, but this model was adjusted for the socioeconomic independent variables. In effect, the regression coefficients (beta values) for each county compare satisfaction in that county to the average satisfaction of all counties assuming constant age, number in family, education, and similar factors. Any differences in the values of the regression coefficients between counties are due to factors other than the independent variables. This approach also allows the betas in Model 1 to be compared to their counterparts in Model 2. Further clarification of the statistical technique is presented in Appendix C.

Other information of value obtained from the two models includes a comparison of the coefficients of determination $\left(\mathrm{R}^{2}\right)$. The difference between the Model $1 \mathrm{R}^{2}$ and that of Model 2 for the same service should be an indication of that explanation of the dependent variable accounted for by the independent variables. The regression coefficients of the independent variables were also of value because they explained the cause of some of the variations in satisfaction with community services.

Tables 11 through 16 show the relevant statistical results for both Models 1 and 2 . All coefficients and $\mathrm{R}^{2}$ values shown were significant at the .05 level or lower. Ambulance service, local road maintenance, neighborhoods, local fire departments, sports and recreation programs, and information about local events or radio were the only services for which statistically significant results were obtained.

$$
\begin{aligned}
\text { Model } 1 \quad Y_{i k} & =B_{o}+B_{1} X_{1}+B_{2} X_{2}+B_{3} X_{3}+e_{i k} \\
Y_{i k} & =\text { Satisfaction of the }{ }_{k} \text { respondents of county } i \cdot
\end{aligned}
$$

${ }^{8}$ Several other models, including linear as well as curvilinear relationships with these and other covariates, were attempted. The best results were obtained with the result discussed in the text.
$X_{1}, X_{2}$ and $X_{3}$ are county location dummy variables where $X_{i}=1$ and all other $X$ 's are 0 .

$\mathrm{X}_{1}=$ Harrison County

$\mathrm{X}_{2}=$ Marion County

$\mathrm{X}_{3}=$ Monongalia County

eik $=$ error term

This model was run for each of the community services.

\section{Model 2}

$$
\begin{aligned}
& Y_{i k}=B_{0}+B_{1} X_{1}+B_{2} X_{2}+B_{3} X_{3}+B_{4} X_{4} \\
& +B_{5} X_{5}+B_{6} X_{6}+B_{7} X_{7}+B_{8} X_{8} \\
& +B_{9} X_{9} \ldots+B_{13} X_{13}+B_{14} X_{14}+\ldots+B_{25} X_{25} \\
& +e_{i k}
\end{aligned}
$$

Where $\quad Y_{i k}=$ Satisfaction of the $\mathrm{k}$ respondents at county $\mathrm{i}$

$\mathrm{X}_{1}=$ Harrison County (county location dummy variable)

$\mathrm{X}_{2}=$ Marion County (county location dummy variable)

$\mathrm{X}_{3}=$ Monongalia County (county location dummy variable)

$\mathrm{X}_{4}=$ Age of household head

$\mathrm{X}_{5}=$ Number in family

$\mathrm{X}_{6}=$ Education of household head (yrs.)

$\mathrm{X}_{7}=$ Household income

$\mathrm{X}_{8}=$ Length of residence

$\mathrm{X}_{9}-\mathrm{X}_{13}=$ Marital status (dummy variable)

$$
\begin{aligned}
& X_{9}=\text { Single } \\
& X_{10}=\text { Married } \\
& X_{11}=\text { Divorced } \\
& X_{12}=\text { Separated } \\
& X_{13}=\text { Widowed }
\end{aligned}
$$

$\mathrm{X}_{14}-\mathrm{X}_{25}=$ Labor force status (dummy variable)

$\mathrm{X}_{14}=$ Working full time; non-farm

$\mathrm{X}_{15}=$ Working part time; non-farm

$\mathrm{X}_{16}=$ Working full time; farm work

$\mathrm{X}_{17}=$ Working part time; farm work

$\mathrm{X}_{18}=$ Looking for work

$\mathrm{X}_{19}=$ Unable to work

$\mathrm{X}_{20}=$ Military service

$\mathrm{X}_{21}=$ Student

$\mathrm{X}_{22}=$ Keep house

$\mathrm{X}_{23}=$ Retired

$\mathrm{X}_{24}=$ Unemployed

$\mathrm{X}_{25}=$ Other

$\mathrm{e}_{\mathrm{ik}}=$ error term 
TABLE 11

Statistical Values Affecting Satisfaction with Ambulance Service

\begin{tabular}{lcc}
\hline \hline Coefficient & Model 1 & Model 2 \\
\hline Coefficient of Determination $\left(\mathrm{R}^{2}\right)$ & .1335 & .2262 \\
Regression Coefficient: & & \\
Harrison & .4682 & .4101 \\
Marion & .3199 & .4367 \\
Monongalia & -.7881 & -.8468 \\
Age of household head & & .0263 \\
\hline
\end{tabular}

TABLE 12

Statistical Values Affecting Satisfaction with Local Road Maintenance

\begin{tabular}{lcr}
\hline \hline Coefficient & Model 1 & Model 2 \\
\hline Coefficient of Determination $\left(\mathrm{R}^{2}\right)$ & .0417 & .1472 \\
Regression Coefficient: & & \\
Harrison & .5600 & .5330 \\
Marion & -.3563 & -.4622 \\
Monongalia & .2037 & .0708 \\
Length of Residence & & -.0295 \\
Married & & -.9581 \\
\hline
\end{tabular}

\section{TABLE 13}

Statistical Values Affecting Satisfaction with Neighborhoods

\begin{tabular}{lr}
\hline \hline Coefficient & Model $\mathbf{1}^{\mathrm{a}}$ \\
\hline Coefficient of Determination $\left(\mathrm{R}^{2}\right)$ & Model 2 \\
Regression Coefficient: & .1533 \\
Housewife & .8463 \\
Single & .7102 \\
Married & .8279 \\
Divorced & -1.4684 \\
\hline
\end{tabular}

${ }^{\mathrm{a}}$ Model 1 was not significant at the .05 level.
TABLE 14

Statistical Values Affecting Satisfaction with Local Fire Departments

\begin{tabular}{lcr}
\hline Coefficient & Model 1 & Model 2 \\
\hline Coefficient of Determination $\left(\mathrm{R}^{2}\right)$ & .0488 & .1597 \\
Regression Coefficient: & & \\
Harrison & .2432 & .2601 \\
Marion & $-\mathrm{a}-$ & $-\mathrm{a}-$ \\
Monongalia & -.3907 & -.4597 \\
Age of Household & & .0215 \\
Unemployed & & -1.7254 \\
\hline
\end{tabular}

${ }^{\mathrm{a}}$ Not significant at the .05 level.

TABLE 15

Statistical Values Affecting Satisfaction

with Sports and Recreation Programs

\begin{tabular}{|c|c|c|}
\hline Coefficient & Model $1^{a}$ & Model 2 \\
\hline Coefficient of Determination $\left(\mathrm{R}^{2}\right)$ & & .1512 \\
\hline \multicolumn{3}{|l|}{ Regression Coefficient: } \\
\hline Number in family & & -.2284 \\
\hline Education of household head & & -.0267 \\
\hline Unemployed & & -2.9607 \\
\hline
\end{tabular}

${ }^{\mathrm{a}}$ Model 1 was not significant at the .05 level.

\section{TABLE 16}

Statistical Values Affecting Satisfaction With Information About Local Events on Radio

\begin{tabular}{lr}
\hline \hline Coefficient & Model 1 \\
\hline Coefficient of Determination $\left(\mathrm{R}^{2}\right)$ & Model 2 \\
Regression Coefficient: & .1616 \\
Working full time, Non-farm & .4924 \\
Unemployed & -2.7548 \\
\hline
\end{tabular}

${ }^{\mathrm{a}}$ Model 1 was not significant at the .05 level. 


\section{Satisfaction with Local Ambulance Service}

The regression analysis indicated that respondents in Monongalia County were less satisfied witth ambulance service than were Harrison and Marion residents (mean satisfac:tion levels, Table 3 ).

The variation in boeta coefficients between Model 1 and Model 2 indicated that a portion of the exxplanation of ambulance satisfaction was due solely to the statistically significant independent variables (in this case, age of household head). The increase in $\mathrm{R}^{2}$ from .13 to .23 indicates this explanation to be about ten percent of the tootal explanation of ambulance satisfaction in the three counties.

A one-year increause in age was associated with a .0263 increase in satisfaction with local ambulance services in the West Virginia sample. The statistical significance of this variable is illustrated in Table 5 .

\section{Satisfaction with Local Road Maintenance}

Marion County resspondents were much less satisfied than were the respondents in Harrison and Monongalia counties with local road maintenance. The Monongalia County sample, however, did not appear to be much greater than average in terms of satisfaction in this category.

The variation between Model 1 and Model 2 and the increase in explanation $\left(\mathrm{R}^{2}\right)$ by adding the in fluence of independent variables indicated that about 11 percent of the variation in satisfaction with local road maintenance was due to length of residence and marital status. As length of residence increased, satisfaction with local roadl maintenance decreased. Also, married respondents were less satisfied than the average of all marital status categories (single, divorced, separated, or widowed ).

\section{Satisfaction with Neighborhoods}

Since Model 1 was not significant at the .05 level and since none of the county location variabsles was found to be significant, the housewife labor force status and marital status appeared to be responsible for about 15 percent of the variation in satisfactiom with neighborhoods.

Divorced respondients were significantly less satisfied with their neighborhoods than the averagee of marital status categories. And housewives were more satisfied than the average of all labor force status categories.

\section{Satisfaction with Locall Fire Departments}

Monongalia County respondents were less satisfied with their fire departments than were Maricon or Harrison County respondents. However, it might be noted that this lower level is still slightly above moderately satisfied (5.09) on the six-point scale (Table 3 ). The other two counties approached the very satisfied level.
The variation between the two mollls indicated that about 11 percent of the variation in total satisfaction was to the significant independent variables. There was an increase in satisfacioon as age increased. And unemployed respondents were significantly less satfied with fire departments than the average of the remaining labor force statis ecategories.

\section{Satisfaction with Sports and Recreation \#rograms}

Since Model 1 was not significant und since the county location dummy variable was not significant, about 15 peceent of the variation in satisfaction was due to the significant variables.

Larger family sizes were associate with less satisfaction with sports and recreation programs. More highly educle this category and unemployed responts were much less satisfied than the average of the labor force status categoris.

\section{Satisfaction with Information About Loall Events on Radio}

About 16 percent of the variation in Ssatisfaction with radio information was due to labor force status. Full-time no-farm workers were more satisfied and unemployed respondents were less satilied than the average of the labor force status categories.

\section{Refeernces}

Beale, Calvin L., The Revival of Populaicon Growth in Non-metropolitan America , ERS-605, Economic Research Srivice, U.S.D.A., June, 1975.

"Community Services for Non-metropliitan People in The Northeast," Project Statement for Northeast Regional Prject Number 77, P. 3.

Marans, Robert W. and Willard Roges, "Toward an Understanding of Community Satisfaction," Institute fo Social Research, The University of Michigan, December 1972 (mimeo).

Rojek, D. G., F. Clemente and G. F.Stummers, "Community Satisfaction: A Study of Contentment with Local Srvices," Rural Sociology, Vol. 40, No. 2, Summer, 1975.

U.S. Department of Commerce, Bureal of the Census, 1970. Census of Population, Vol. 1, U.S. Summary.

U.S. Department of Commerce, Butauu of Economic Analysis 1972 Obers Projections, Regional Economic Alivity in the U. S., Series E. Population, Volume I, Concepts, Methodology aed Summary Data. U. S. Water Resources Council, April, 1974. 


\section{Appendix A}

\section{SAMPLING PROCEDURE}

This study was conducted as part of the effort of a Northeast Regional Research Committee (NE-77). The committee was primarily interested in the delivery of community services to non-metropolitan people in the Northeast.

The non-metropolitan sector for this research project was defined as those people living in counties with a 30 percent or greater non-urbanized population. This criterion included those standard metropolitan statistical area (SMSA) counties which may have had fairly large proportions of rural population. Using this criterion, 245 non-metropolitan counties were identified and classified on the basis of population change (1960-70) and income change (1960-70). This was done in order to select "more developing" and "less developing" counties for inclusion in the analysis.

The actual procedures for classifying counties by population and income change involved the construction of two arrays of the 245 non-metropolitan counties - one by percentage population change 1960-70, and the other by percentage change in median family income 1960-70. Using these arrays, the following types of counties were identified.

1. Expanding (E) - counties located both in the highest quintile of population increase and highest quintile of income increase.

2. Stable (S) - counties located both in the middle quintile of population increase and middle quintile of income increase.

3. Declining (D) - counties located both in the lowest quintile of population increase and lowest quintile of income increase.

The arraying of counties in the three quintiles on both variables simultaneously resulted in the grid portrayed in Figure 1.

It was assumed that a probability sampling method for selecting counties in the EE, SS, and DD "cells" would result in adequate geographic dispersion. However, two states, Massachusetts and Connecticut, were found to have no counties in the three cells. Connecticut had one county and Massachusetts two, whose rates of population and income change were determined to be close enough to the limits of one of the three categories to allow their inclusion in the corresponding category. Thus, counties were selected along the diagonal as indicated in Figure 1

${ }^{9}$ This section was adopted from a description of the regional sampling procedure by Dr. Charles Crawford, Dept. Rural Sociology, Penn State Univ., and Dr. Donn Derr, Dept. of Agr. Econ., Rutgers University. 
Appendix Figure 1. Generalized Sampling Model for Community Services

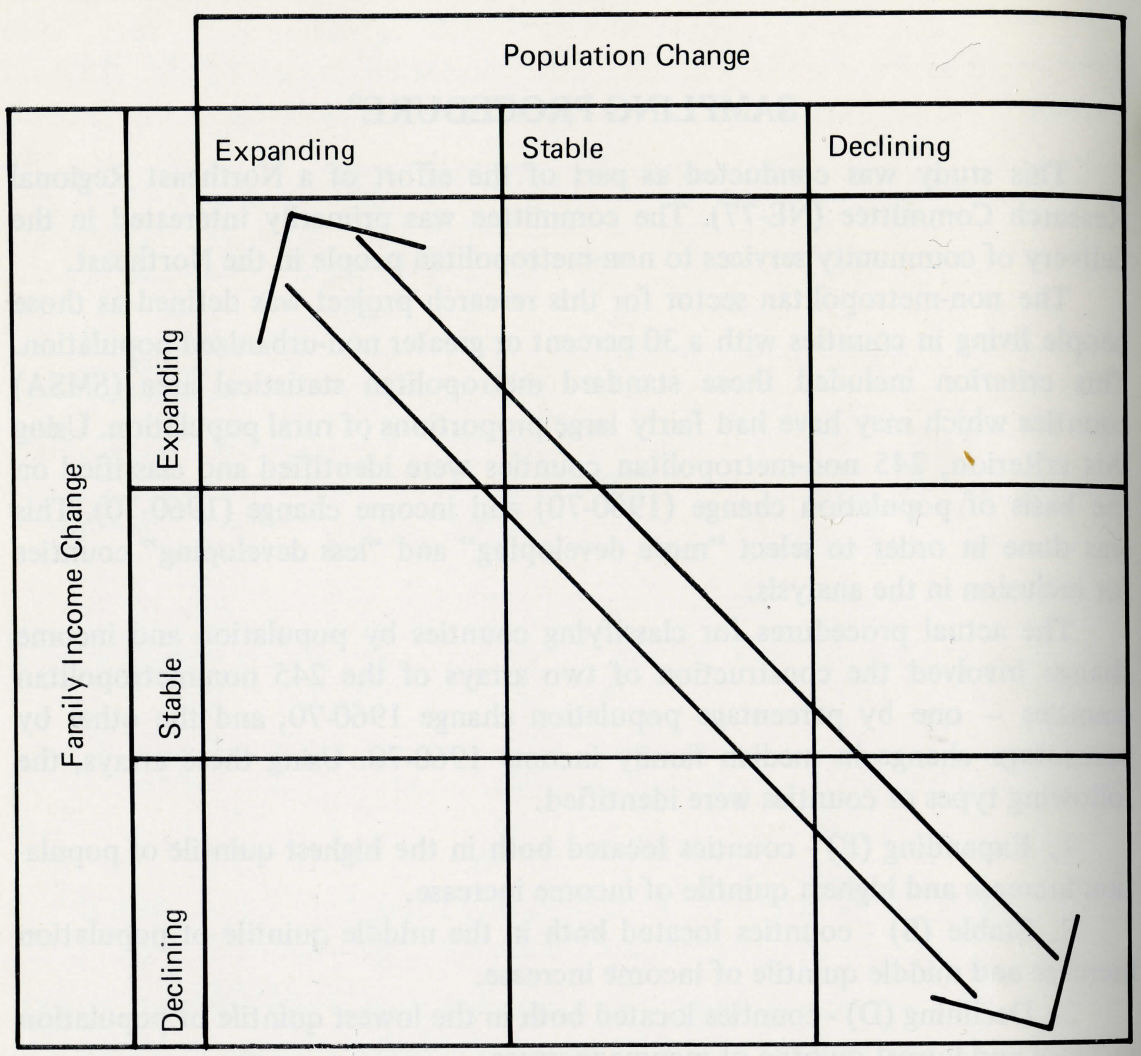

After identifying the counties in the cells on the diagonal, each state selected those counties in which the study was to be conducted. In five states minor civil divisions (MDC's) within each county were selected; within stable counties, only stable MCD's were selected, and within declining counties, only declining MCD's were selected. The criterion for classifying MCD's as expanding, stable, or declining was their rank on 1960-70 population change among all MCD's within their respective states. Income data were not available for all MCD's; thus, it was not included for purposes of stratification. Again, as in the classification of counties, quintiles were used. Those MCD's in the highest quintile were labeled as expanding, those in the third quintile as stable, and those in the bottom quintile were classified as declining. By selecting expanding MCD's for expanding counties, stable ones for stable counties, and declining ones for declining counties easier interpretation of the growth-development status of the selected site could be made. For example, data from an expanding MCD in a declining county could lead to various research interpretations.
For the nine northeastern states participating in the consumer phase of the project, 65 sites met the established criteria. From these initial 65 sites, 22 were selected in the nine-state area. Six sites were expanding (EE), seven were categorized as stable (SS), and nine were considered to be declining (DD). In order to have a reasonable " $n$ " to use in statistical analyses, MCD sites located within four counties were grouped together. The researchers at the respective stations where this was done felt the findings would not be jeopardized by such groupings. The four instances where such groupings were established included the MCD's located in the following counties: (1) three MCD's in Kennebec County, Maine; (2) three MCD's in Coos County, New Hampshire; (3) three MCD's in Essex County, Vermont; and (4) three MCD's in Chittenden County and one MCD in Grand Isle County, Vermont.

As a result of the above groupings a total of 15 sites was eventually specified for study. It is important to note that the term "site" as used in this study, then, may refer to a single MCD, a grouping of contiguous MCD's, a county, or combination of counties.

\section{Household Selection at the MCD or County (Control Unit) Level}

At the control unit level (MCD or county), each site was stratified on the basis of population density. A grid map was first developed and the number of households in each cell was counted. If a cell contained more than seven households, it was further subdivided until three to seven households existed per cell. The cells were then numbered and randomly selected so that there would be a minimum sample of 100 per control unit (MCD or county). For more densely populated areas, census tracts or city blocks were used initially. Further grid subdivisions were made until each had three-seven households. For the cells selected (three-seven housholds in each) a responsible adult in each household was interviewed. An exception to this procedure was the method used in Cameron County, Pennsylvania. Preliminary investigation revealed an extremely large number of "hunting camp residences." Since there was no way of determining whether these "residences" were occupied, and since population density was so low (17.7 persons per square mile in 1970), it was decided to systematically random sample from a list of all persons 18 years of age and over, which was maintained in county records. The households in which these selected persons lived were then selected as the sample households. Some states like Vermont used the poll tax list as an acceptable substitute for the grid method.

This procedure provided a sample that reflected geographic dispersal of households (the basic consuming unit) which would permit the testing of the hypothesis that location or distance affected or acted as a barrier to community service use. Interviews took place in 2,141 households. The typical interview took about 45 minutes. An average of two cells were required per completed questionnaire. 


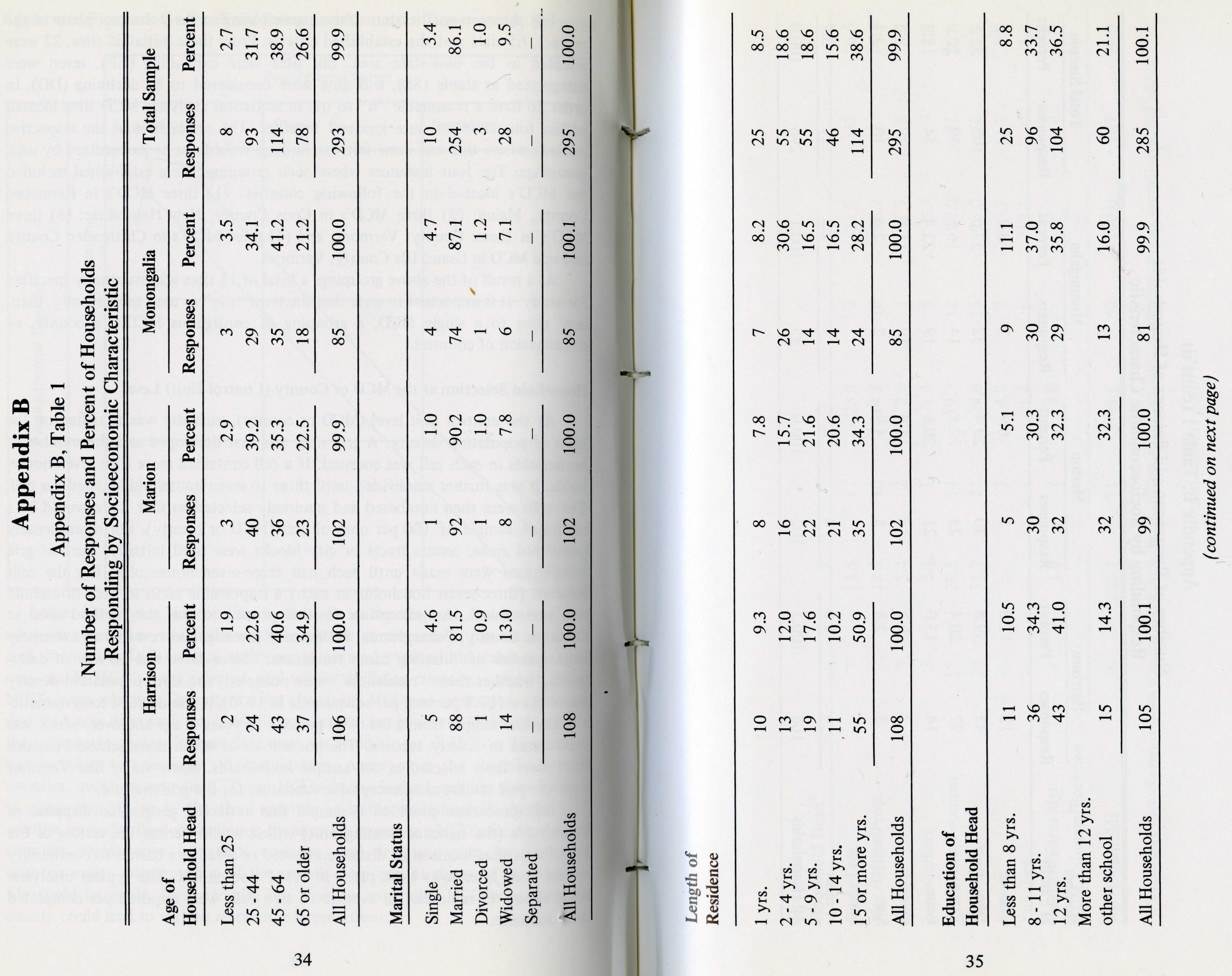




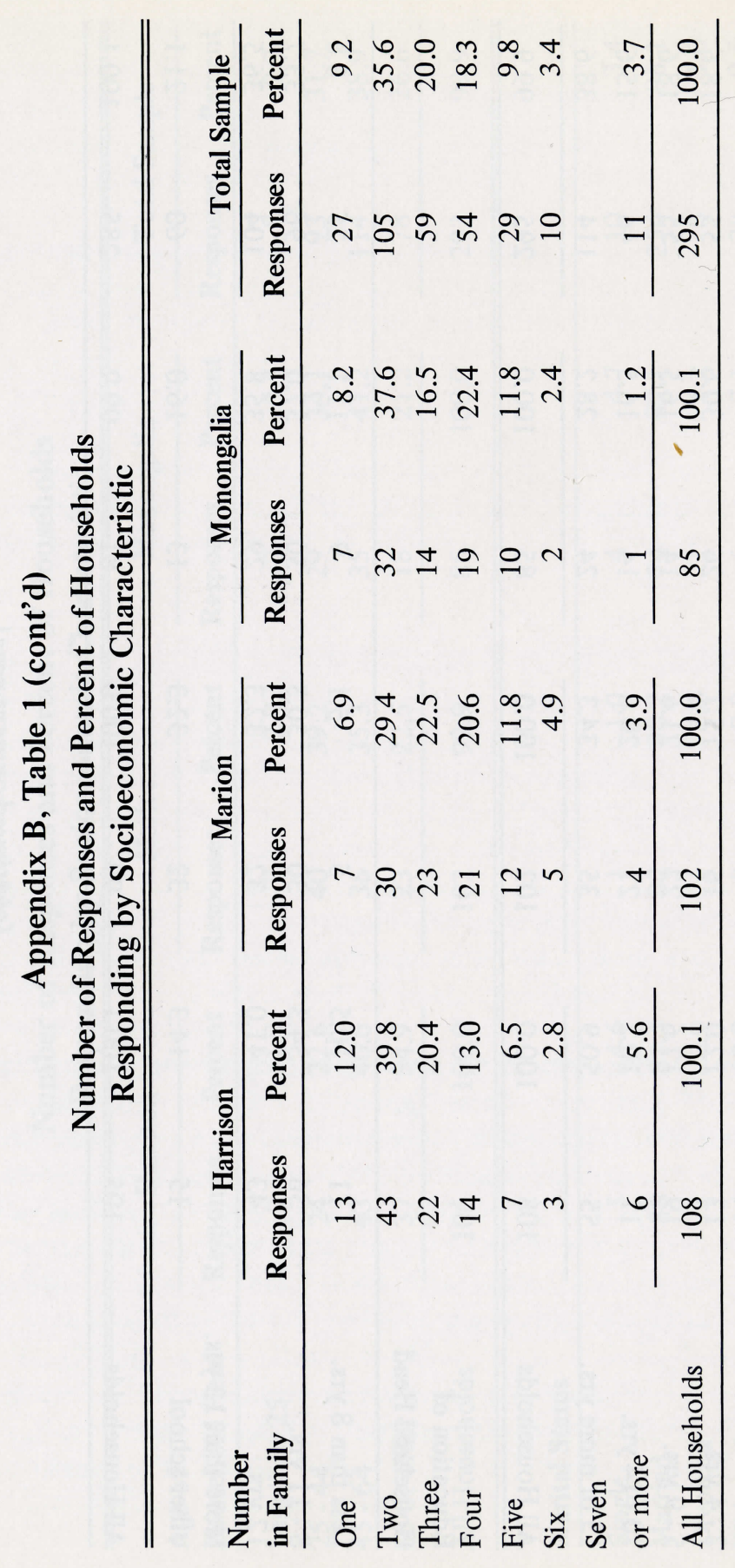

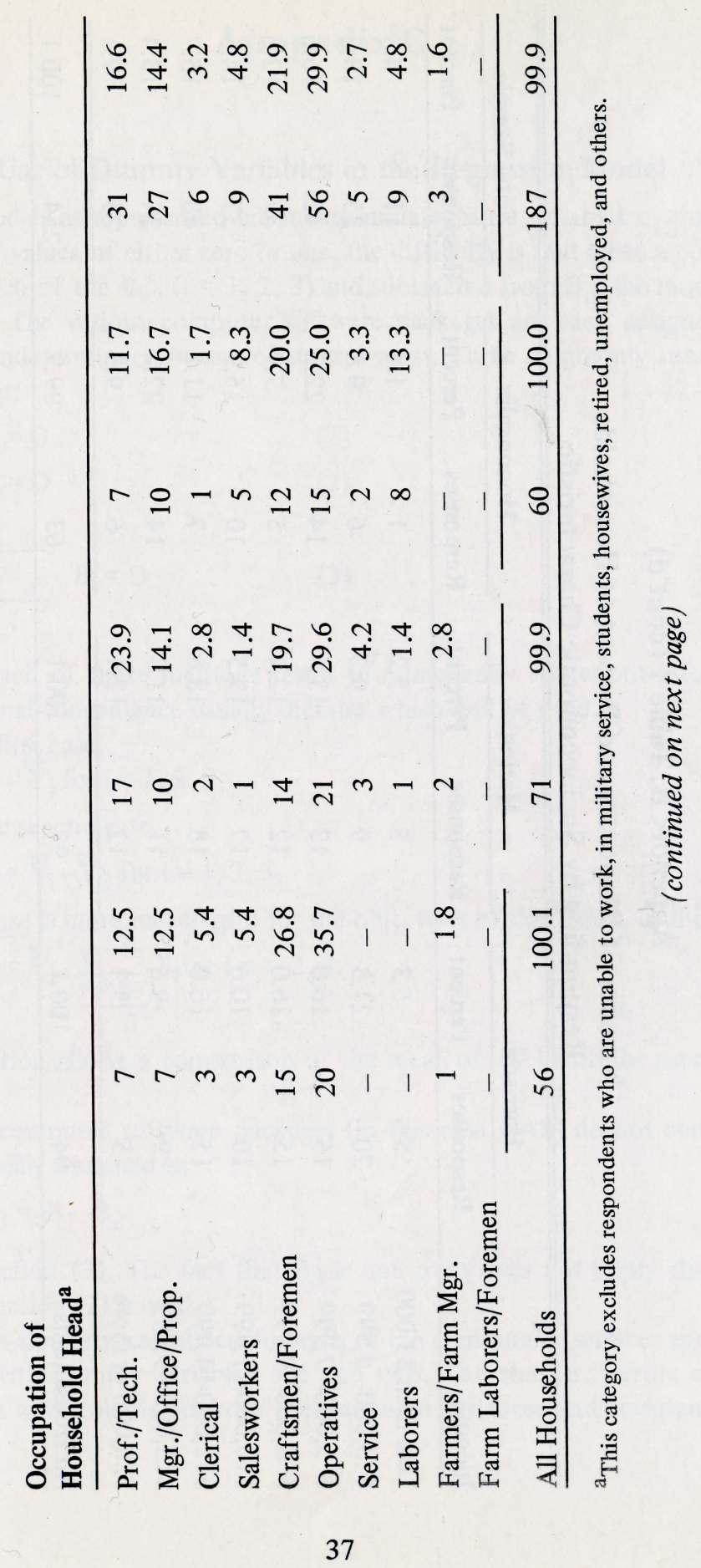




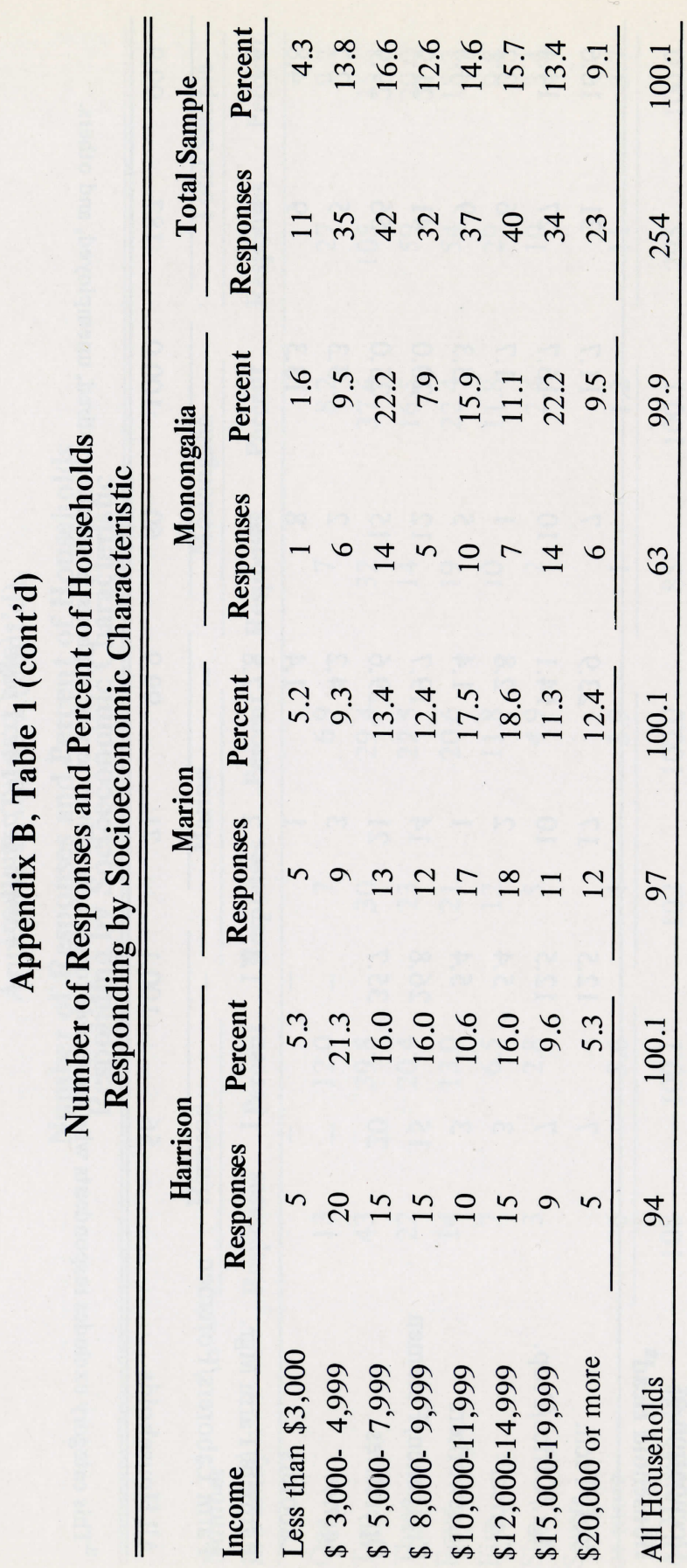

\section{Appendix C}

\section{Use of Dummy Variables in the Regression Model}

The models as represented are indeterminate. Since variables $\mathrm{x}_{1}$ through $\mathrm{x}_{3}$ are assigned values of either zero or one, the difficulty is that when a constant is added to each of the $B_{i}$ 's $(i=1,2,3)$ and subtracted from $B_{O}$, the model is left unchanged. The various computer software packages are each designed to remove this indeterminacy in one of several ways. Three commonly used restrictions include:

$$
\begin{aligned}
& \mathrm{B}_{\mathrm{O}}=0 \\
& \mathrm{~B}_{3}=0 \\
& \sum_{\mathrm{i}=1}^{3} \mathrm{~B}_{\mathrm{i}}=0
\end{aligned}
$$

Although each of these methods result in numerically equivalent information, computational convenience usually dictates which will be used.

In the first case,

$$
\mathrm{B}_{\mathrm{i}}=\overline{\mathrm{Y}}_{\mathbf{i}} \text { for } \mathrm{i}=1,2,3,
$$

where in the second case,

$$
B_{i}=\bar{Y}_{i}-\bar{Y}_{3} \text { for } i=1,2,3 \text {. }
$$

The third case is more meaningful for the objectives of this study. In this case,

$$
B_{i}=\bar{Y}_{i}-\frac{\sum_{i=1}}{3} \bar{Y}_{i} \text { for } \mathrm{i}=1,2,3 .
$$

This restriction allows a comparison of the mean of site $i$ with the average of all site means.

Many computer software packages (in this case, SAS) do not compute $\mathrm{B}_{3}$ since it is easily obtained as

$$
\mathrm{B}_{3}=-\mathrm{B}_{1}-\mathrm{B}_{2}
$$

from restriction (3). The fact that $B_{3}$ is not given does not imply that $B_{3}=0$ unless restriction (2) is used.

$\mathrm{B}_{3}$ was similarly calculated for each of the community services and presented along with dummy variables one and two. The standard errors of the $B_{3}$ coefficients were calculated from the estimated variances and covariances of $\mathrm{B}_{1}$ and $\mathrm{B}_{2}$. 